\title{
Fourth Ventricle and Brain Stem Ependymal Tumor
}

National Cancer Institute

\section{Source}

National Cancer Institute. Fourth Ventricle and Brain Stem Ependymal Tumor. NCI

Thesaurus. Code C131596.

An ependymal tumor affecting the fourth ventricle and the brain stem. 